https://doi.org/10.17048/AM.2020.84

\title{
Balázs Brigitta
}

Eszterházy Károly Egyetem Neveléstudományi Doktori Iskola

balazs.b@index.hu

Molnár György

Budapesti Müszaki Egyetem, Müszaki és Pedagógia Tanszék

molnargy@eik.bme.hu

\section{A digitalizáció szerepe a pályaválasztásban - a digitalizáció hatása a foglalkoztatásra - digitális oktatás hatása a pályaorientációs fo- lyamatban}

\section{Absztrakt}

Tanulmányunk során a feltárt adatok legfontosabb eredményei kerülnek bemutatásra, amelynek elemzése során három fő hipotézis kerül igazolásra és cáfolásra. A digitális oktatásnak, a digitalizáció munkaerőpiaci szerepének gyakorlati relevanciáját mi sem támasztja jobban alá, mint az elmúlt időszak járványügyi helyzete miatt kialakult digitális munkarend alkalmazása mind az oktatás terén, mind pedig a Home office rendszerbe kényszerülő munkavállalók esetében. A kapott eredményeink segíthetnek megismerni a digitalizáció hatásait a pályaorientációs folyamatokra, amely segítségével meghatározhatók a jövőbeli előremutató irányvonalak a pályaszocializáció ösztönzésére.

Kulcsszavak: digitalizáció, IKT, pályaorientáció, digitális nemzedék

The role of digitalization in career selection - the impact of digitalization of emloyment - the influence of digital instruction ont he career guidance process

Our paper introduces the analysis of the most important research results facilitating the substantiation and refutation of three hypotheses. The practical relevance and necessity of digital instruction and the increased importance of digitalization in the labour market are best illustrated by the introduction of digitally scheduled education and the application of the Home Office method in the business world as a result of the COVID-19 pandemic. Our research results can provide a glimpse at the 
impact of digitalization on career guidance processes while forecasting future trends encouraging career socialization.

Keywords: digitization, ICT, career guidance, digital generation

\section{Bevezetés}

Napjainkban a digitalizáció az élet minden területén jelen van, amely a versenyképesség, a jólét, a fejlődés legfőbb hajtóereje. Az infrastruktúra, a humán erőforrások, az oktatás és képzési rendszerek digitális fejlesztése elengedhetetlen feladat a gazdasági növekedés és az életszínvonal emelkedése érdekében. A digitális kompetencia a munkaerőpiac által is elvárt alapkészség, amelynek elsajátítása alapvetően az oktatási és képzési rendszer feladata. A magyar kormány is felismerve ennek jelentőségét, a 2016. évtől kezdődően létrehozta a digitális jólét programot, amelynek célja, hogy felkészítse az oktatást a digitális társadalom és gazdaság igényeinek megfelelő nevelési, oktatási és képzési feladatainak ellátására. A stratégia szándéka, hogy senki ne hagyja el úgy az iskolát, hogy a munkaerőpiac által elvárt digitális alapkészségekkel ne rendelkezne, megteremtve ezzel a foglalkoztatottság és a munkaerőpiaci versenyképesség alapjait. A pályaválasztás egy nagyon összetett rendszer, és egyben az egyik legfontosabb döntés a diákok életében, magába foglalja az iskolai szolgáltatást, az egyéni képességét, valamint a szakképzés-politikai rendszert is. A pályaorientáció fogalmát így határozzák meg hazai szerzők: „azoknak a személyes kompetenciáknak, készségeknek a megszerzését jelenti, amely előkészíti az ember - pálya - környezet megfeleltetését. Ebből következik, hogy nem csupán a különböző szakmákról, de önmagunkról, és a minket körülvevő társadalmi környezetről szerzett ismereteket is magába foglalja. Így a pályaorientáció segít összhangba hozni az egyéni készségeket, a társadalmi igényekkel és a választott szakmával” (R. Bögös és V. Dávid, 2003).

$A$ pályaválasztásban érintett $Z$ generáció tagjainak a mindennapi élet része a digitális eszközök használata, hiszen ők már teljesen átálltak erre a világra (Racsko, 2017), állandó online üzemmódban vannak (Szúts, 2018), de fontos-e nekik a leendő munkájuk kiválasztásakor, hogy elektronikus térben múködjenek, befolyásolja-e döntésüket, hogy olyan helyet válasszanak, ahol az alapvető munkaeszköz az IKT. Rendelkeznek-e felhasználói szintű kompetenciákkal vagy csak megragadtak a Google-n történő keresésnél. A válaszok a kutatás eredményeként kerülnek bemutatásra a tanulmányban.

\subsection{A kutatás célja}

A kutatás célja annak felmérése

- hogy a pályaválasztás során mennyire befolyásolja a diákokat a digitális eszközök használta, azaz számít-e, hogy leendő munkájuk során alkalmazzák-e majd az IKT eszközöket?

- Használnak-e a tanórákon digitális eszközöket és ha igen, milyen formában? 
- Milyen tényezők befolyásolják legjobban a pályaválasztásban a diákokat?

- Van-e összefüggés az iskolai végzettség szintje és a digitalizációs pályaválasztás között?

- Milyen szintű digitális kompetenciával rendelkeznek?

- Milyen módon sajátítják el a digitális eszközök használatát?

\subsection{A kutatás módszere, célcsoportjai}

A kutatás célcsoportja a Z-generáció vagyis az 1995-2009 között született jelenleg általános iskolás és felsőfokú intézménybe járó diákok. A megkérdezettek köre:

- általános iskola felső tagozatos tanulói

- szakközépiskola tanulói

- szakgimnázium tanulói

- gimnázium tanulói

- felsőfokú intézmény tanulói

Az alkalmazni kívánt módszer választása a kvantitatív, primer kutatás keretében felmért kérdőíves megkérdezés, amely a Google Ûrlapok webes felületén történt, a gyors és széles célcsoportot azonnal elérő lehetőség miatt.

\subsection{A kutatás hipotézisei}

A kutatás első hipotézise, hogy a magasabb iskolai végezettséget választók esetében a pályaválasztás során az érdeklődési kör a legbefolyásolóbb tényező.

A második hipotézis, hogy az iskolai végzettség és a digitális pályaválasztás között szoros összefüggés van, azaz a magasabb végzettséget választó diákok, olyan pályát választanak, ahol az IKT eszköz már a mindennapi munkavégzés része és az innováció folyamatosan jelen van. Fontos számukra az elektronikus környezet.

A harmadik hipotézis, hogy a vizsgált csoport, több mint 65\%-a középszintű digitális felhasználó, akik autodidakta módon sajátították el az elektronikus rendszerek használatát.

\section{A kutatási eredmények bemutatása}

A kutatás fókuszában a Howe és Strauss (2000) féle generációs felosztásból a Z generáció állt, akikkel kapcsolatban a pályaválasztás során a digitális eszközök alkalmazásának befolyásolását vizsgáltuk. Az eddigi tapasztalataink alapján elvileg az ő célcsoportjuknál természetes az IKT eszközök és rendszerek alkalmazása, amit a mindennapokban használnak, de ezzel együtt minket az érdekelt, hogy előnyben részesítik-e vagy figyelembe veszik-e ezeket a pályaorientációs folyamatokban, a karriertervezés és továbbtanulás rendszerében. 
A vizsgált célcsoportot egy kvantitatív alapú kérdőíves felmérés útján kérdeztük meg a Google Ûrlapok szolgáltatása segítségével. A kapott adatok feldolgozását az SPSS 22 statisztikai elemző program támogatásával végeztük el. A beérkezett válaszok száma $\mathrm{N}=130$ fő volt, amelynek nemek szerinti megoszlása $40 \%$ férfi és $60 \%$ nő. A legfiatalabb válaszadó 13 éves, a legidősebb 26 éves volt, az átlagéletkoruk 19 év, a kitöltők több mint 70\%-a középiskolába jár. Az elérni kívánt iskolai végzettség legmagasabb aránya az egyetemi végzettség, vagyis a válaszadók 73\%-a szeretne diplomát szerezni a jövőben.

A személyes kérdéseken túl felmértük milyen digitális platformokat használnak az őket oktató pedagógusok. A legtöbbet alkalmazott digitális felület a Zanza.tv (70\%), a Kahoot (69\%), a Google Classroom (54\%) és az interaktív tábla (46\%). A diákok közül 6 fő jelezte, hogy nem használnak egyáltalán IKT eszközöket, ami a megkérdezettek alig 4\%-a. E kapott eredmények nagyrészt hasonlóságot mutatnak a pandémia időszakában végzett hazai (Balogh et. al. 2020) és nemzetközi empirikus kutatások (Námesztovszki et. al. 2020) eredményeivel is, árnyalatbeli különbségek tapasztalhatók a különböző országok vagy iskolafokok tekintetében.

A kutatás következő részében, azt vizsgáljuk, hogy a pályaválasztást milyen tényezők befolyásolják, milyen tényezők vannak hatással a továbbtanulásra? A tanulók rangsorolhattak az érdeklődési kör, a szülői javaslat, a pályaválasztási tanácsadó hatása és a barát/barátnő befolyásolása között. Általános esetben a diákok kétszer választanak iskolát, egyszer 8. és egyszer pedig 12. évfolyamon. A kérdőívben így külön mértük fel a középfokú iskolát illetve a felsőfokú intézményt választani akarókat, mert az életkori sajátosságokat is figyelembe vettük. Az ehhez a kérdéskörhöz tartozó eredményeket az 1. táblázat mutatja be, amely alapján mindkét esetben a leggyakoribb és legbefolyásolóbb tényező az érdeklődési kör, azaz úgy választanak iskolát, ami legközelebb áll hozzájuk. Emellett hatással van rájuk a szülők javaslata, ami a második befolyásoló tényező a relatív gyakoriság szerint, kevésbé befolyásoló a pályaválasztási tanácsadó, valamint egyáltalán nincs ráhatása a barát/barátnő véleményének illetve az ő iskolaválasztásuknak. Az új szakképzés 4.0 stratégiája szerint: „A jelenleg múködő pályaorientáció „nagyrendezvény” központú, ahol elsősorban az iskolák bemutatása és az információs anyagok átadása a cél. A „Z” generációhoz tartozó pályaválasztó fiatalok számára nem ezek a szituációk a legfontosabbak a megfelelő pálya kiválasztásában.” (Szakképzés 4.0, 2020) Új élményalapú pályaválasztási lehetőségekre fektetik a hangsúlyt, ilyenek például a Digitális Közösségi Alkotóhelyek, szakkörök szervezése, tematikus nyári táborok, Példakép-program valamint „Egy nap a munkahelyen”. Ezekben a megújult pályaorientációs programokban a szakterületek megismerésében a diákok érdeklődési köre is szerepet játszik, hiszen azokra a szakmákra kíváncsi, ami hozzá a legközelebb áll. 


\section{1. táblázat A pályaválasztást befolyásoló tényezők, saját táblázat}

\begin{tabular}{|c|c|c|c|c|c|c|c|c|}
\hline \multirow[b]{2}{*}{ Pályaválasztás szintje } & \multicolumn{2}{|c|}{ Legjobban befolyásoló tényezö } & \multicolumn{2}{|c|}{ Befolyásoló tényező } & \multicolumn{2}{|c|}{ Kevés bé befolyásoló tényező } & \multicolumn{2}{|c|}{$\begin{array}{c}\text { Egyáltalán nem befolyásoló } \\
\text { tényező }\end{array}$} \\
\hline & Megnevezés & $\begin{array}{c}\text { Relatív } \\
\text { gyak. \% }\end{array}$ & Megnevezés & $\begin{array}{r}\text { Relatív } \\
\text { gyak. \% }\end{array}$ & Megnevezés & $\begin{array}{r}\text { Relatív } \\
\text { gyak. \% }\end{array}$ & Megnevezés & $\begin{array}{r}\text { Relatív } \\
\text { gyak. \% }\end{array}$ \\
\hline Középis koli továbbtanulás & érdeklődési kör & 67,70 & Szz̈lői javaslat & 40,00 & $\begin{array}{c}\text { Pályaválasztási } \\
\text { tanácsadó }\end{array}$ & 36,90 & Barát/Barátnő & 59,20 \\
\hline Felsőfokú is kolai tovább tanulás & érdeklődési kör & 77,10 & Szülöi javas lat & 41,40 & $\begin{array}{c}\text { Pályaválasztási } \\
\text { tanácsadó }\end{array}$ & 44,30 & Barát/Barátnő & 58,60 \\
\hline
\end{tabular}

Az első hipotézis alapgondolata, az hogy a magasabb iskolai végzettséget választóknál az érdeklődési kör a legbefolyásolóbb tényező, amit a 2. táblázat igazolt is a számításaink alapján. Az eredmények a kereszttábla elemzés szerint azt mutatják, hogy mind az egyetemi végzettséget választók, mind a közép- és felsőfokra tovább tanulók esetében az érdeklődési kör a legmagasabb arányú, ezáltal hipotézisünk igazolást nyert.

\section{2. táblázat Az érdeklődési kör befolyásoló szerepe, saját táblázat}

\begin{tabular}{|c|c|c|c|c|c|c|c|c|}
\hline \multirow[b]{2}{*}{ Végzettség szintje } & \multicolumn{4}{|c|}{ Középisk. pályaválasztás nál érdeklődési kör } & \multicolumn{4}{|c|}{ Felsőfokú pályaválasztásnál érdeklődési kör } \\
\hline & $\begin{array}{l}\text { Nem } \\
\text { befolyás ol }\end{array}$ & $\begin{array}{l}\text { Kevés bé } \\
\text { befolyás ol }\end{array}$ & Befolyás ol & $\begin{array}{l}\text { Legjobban } \\
\text { befolyás ol }\end{array}$ & $\begin{array}{l}\text { Nem } \\
\text { befolyásol }\end{array}$ & $\begin{array}{l}\text { Kevésbé } \\
\text { befolyás ol }\end{array}$ & Befolyásol & $\begin{array}{l}\text { Legjobban } \\
\text { befolyásol }\end{array}$ \\
\hline Szakközépisk. bizonyítvány & 0 & \begin{tabular}{|l|}
0 \\
0
\end{tabular} & 2 & 1 & 0 & 0 & 0 & 1 \\
\hline Érettségi bizonyítvány & 0 & 1 & 2 & 6 & 0 & 0 & 0 & 2 \\
\hline OKJ bizonyítvány & 0 & 3 & 4 & 10 & 1 & 0 & 1 & 3 \\
\hline Egyetemi diploma & 2 & 2 & 25 & 66 & 0 & 2 & 11 & 46 \\
\hline Doktori PhD cím & 0 & 0 & 1 & 5 & 0 & 0 & 1 & 2 \\
\hline
\end{tabular}

A második hipotézis szerint az iskolai végzettség és a digitális típusú pályaválasztás között szoros összefüggés van, azaz a magasabb végzettséget választó diákok, olyan pályát szeretnének, ahol az IKT eszközök már a mindennapi munkavégzés részei, és az innováció folyamatosan jelen van. Az erre vonatkozó eredményeket a 3. és 4. táblázat tartalmazza.

3. táblázat Összefüggés a leendő munkahelyi digitalizáció és az iskolai végzettség között, saját táblázat

\begin{tabular}{|ll|r|r|r|}
\hline & & \multicolumn{2}{|c|}{ Befolvásolia-e a munt } \\
\cline { 3 - 4 } & & Egyahelvi digit. & \\
& & Igen, befolyásón nem & \\
befolyásol & Total \\
\hline Milyen végzettséget & Szakközépiskolai & 1 & & \\
szeretne & bizonyítvány/szakvizsga & 2 & 3 \\
& Érettségi bizonyítvány & 1 & 8 & 9 \\
& OKJ bizonyitvány & 5 & 12 & 17 \\
& Egyetemi diploma & 38 & 57 & 95 \\
& Doktori PhD cím & 2 & 4 & 6 \\
& & 47 & 83 & 130 \\
\hline
\end{tabular}




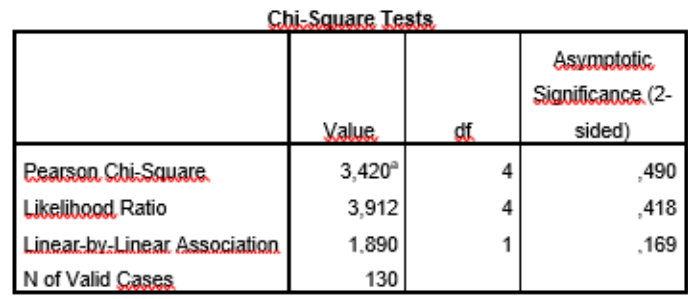

a. 5 cells $(50,0 \%)$ baxe expected count less than 5 . The minimum expected count is 1,08 .

A Khi négyzet próba statisztikai mutató segítségével bizonyítjuk vagy cáfoljuk, hogy a két változó között van-e szignifikáns kapcsolat, az elemzésünk során így a végzettségi szint és a leendő munkahelyi digitalizácó szerepe között nincs összefüggés, mivel $p>0,05$ azaz a vizsgált célcsoportot nem befolyásolja, hogy leendő munkahelyén elektronikus környezetben fog-e dolgozni vagy sem. A hipotézis a számított eredmények alapján nem nyert bizonyítást.

A harmadik hipotézis szerint a vizsgált csoport nagy része, több mint 65\%-a középszintű digitális felhasználó, akik autodidakta módon sajátították el az elektronikus rendszerek használatát. A kérdőívben a vizsgálat tárgya a digitális kompetencia felmérése volt, amelyben a diákok választhatták ki a szerintük vélelmezett szintjüket, viszont a kiválasztás után kontrollkérdésként a szintnek megfelelő szakmai kérdést kaptak, ha ezekre a kérdésekre nem tudták a helyes választ, akkor nem feleltek meg a szint elvárásainak, így visszakerültek az eredeti szintválasztó kérdéshez és újra kellett felelni a feltett kérdésre. A kontroll kérdések alkalmazása így kizárta, hogy a válaszadók ne a valós digitális kompetencia kvalitását adják meg. Az alapszintű kérdéseknél az okostelefonok használata, böngészés a neten, a középfokúnál a különböző programok ismerete (Ms Power Point, Excel Word, a felsőfokú szintnél a programnyelvek ismerete, a tartalomfejlesztés volt a mértékadó és az ehhez kapcsolódó szintfelmérések is ide kapcsolódtak.

4. táblázat A felmérés digitális kompetencia szintjei, saját táblázat

\begin{tabular}{|ll|r|r|r|r|}
\hline & Frequency & Percent & Valid Percent & $\begin{array}{c}\text { Cumulative } \\
\text { Percent }\end{array}$ \\
\hline Valid & Alapszintũ felhasználó & 13 & 10,0 & 10,0 & 10,0 \\
& Középszintũ felhasználó & 109 & 83,8 & 83,8 & 93,8 \\
& Magasszintũ felhasználó & 8 & 6,2 & 6,2 & 100,0 \\
& 130 & 100,0 & 100,0 & \\
\hline
\end{tabular}

A 4. táblázatból látható, hogy a vizsgált csoport 83,8\%-a középszintűnek gondolja magát és az ehhez kapcsolódó ellenőrző kérdésnek is megfeleltek, így a feltételezésünk igazolást nyert. A kérdések csak az IKT eszköz ismeretétét, a programok használatát mérték fel, az adatfeldolgozást, információszerzést, problémamegoldást nem. A felmérés eredményeiből arra következtethetünk, hogy a diákok otthonosan mozognak az IKT világában, de elegendő-e ez ahhoz, hogy a digitális készségüket a fel- 
adatmegoldás, információkeresés és feldolgozás során eredményesen alkalmazni is tudják. Egy 2018ban felmért tanulmány szerint: „ a diákoknak főként az okoz fejtörést, ha a világhálón kell válaszok után kutatniuk, majd mérlegelni és értékelni a találtakat. A célzott internetes keresés, az adatfeldolgozás és az álhírek felismerésének képessége a tesztet kitöltő intézmények mindegyikében fejlesztésre szorul. A többi négy dimenzióban (problémamegoldás, biztonság, tartalomelőállítás, kommunikáció) átlagosan jobb, 50\% feletti eredmények születtek, de nagyobb szórással, így jól látható, hogy hol van az adott iskolában lemaradás, mit érdemes beépíteni a jövőben a tananyagba (Microsoft, 2018).

$\mathrm{Az}$, hogy ezeket a digitális készségeket, hogyan és honnan sajátítják el, nagyban befolyásolhatja azt is, hogy megfelelően tudják-e alkalmazni ezeket. Kérdőívünkben az utolsó kérdéskör ezzel a problémával foglalkozott, amiben a kérdőívet kitöltők arra válaszoltak, hogy a digitális kompetenciájukhoz milyen tényező járult hozzá a legjobban (1. ábra).

\section{1. ábra A digitális kompetencia elsajátítása, saját ábra}

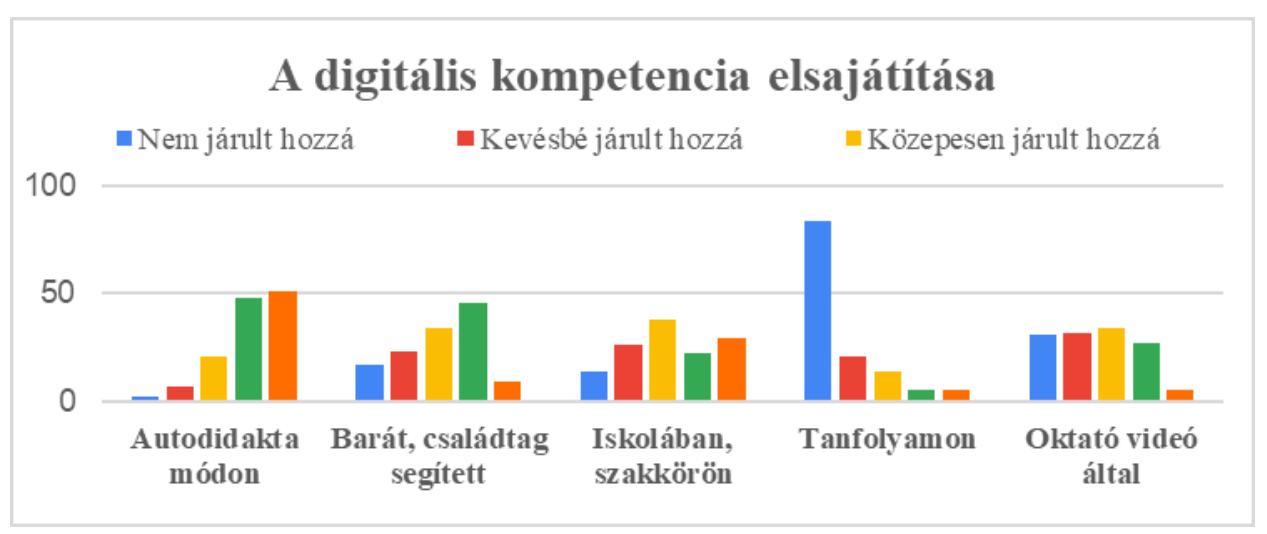

A fenti válaszlehetőségek közül a legnagyobb mértékben az autodidakta mód járult hozzá a digitális készségek elsajátításához a válaszadók szerint, azaz a diákok leginkább saját maguk tanulják meg az IKT eszközök használatát. A Z-generáció sajátossága, hogy tanúja számos elektronikus szerkezet és technológia széles körű fejlődésének (internet, social média stb.), jártas a technológia világában, globálisan bekapcsolódott a világhálóba. (Grail Research 2011) A digitális korral együtt nőnek fel, ebből adódóan kiválóan értenek az internethez, hamar kiismerik magukat az újabb és újabb technológiák világában (Pál-Törőcsik, 2013). A programok, okoseszközök használatával így bátran kísérleteznek, tapasztalataikat szívesen megosztják egymással, tanítva, segítve ezzel az elektronikus környezet megismerését. Empirikus kutatásunkban is a második tényezőként szerepelt a barátoktól, családtagoktól, ismerősöktől való segítségkérés, amely hozzájárult a digitális kompetenciájuk kialakulásához. Az iskolában, a szakkörökön való elsajátítás, közepesen járult hozzá ennek a készségnek a fejlesztéséhez. Az oktatási rendszernek is lépést kellene tartani a technológia fejlődésével, nem hagyhatja figyelmen kívül a virtuális valóság egyre szélesedő kiterjesztését. Kormányzati oldalról is nagy felelősség ennek 
fejlesztése, mert az infokommunikációs készség a munkaerőpiac oldaláról is erős elvárásokat diktál a leendő munkavállalók számára. A biztonságos digitális tudáshoz nem elég csak „digitális bennszülöttnek" (Prensky, 2001) vagy „digitális beavatottnak” (Z. Karlovits, 2019) lenni, meg kell tanítani ezt a generációt a tudatos internethasználatra, az információk kezelésére és a problémák megoldására. Ennek hatékony kezelésére készült el 2018-ban a digitális Gyermekvédelmi Stratégia koncepciója, amely sokat segíthet a problémák megoldásában. Emellett „A Kormány az InternetKon eredményei alapján készítette el a magyar társadalom és a magyar nemzetgazdaság digitális fejlesztését célzó Digitális Jólét Programot (DJP). A programot és az annak részeként elkészült Magyarország Digitális Oktatási Stratégiáját (DOS) az a felismerés hívta életre, hogy a digitális átalakulás nem választás kérdése: olyan elkerülhetetlen jelenség, amelyre mindenkinek fel kell készülnie, hiszen 20. századi tudással senki nem lehet versenyképes a 21. században. A digitális eszközöket és szemléletmódot be kell vinni a tantermekbe, mivel napról napra mélyebben integrálódnak a hétköznapi életünkbe is." (Digitális Oktatási Stratégia 2016). A korszerű oktatási stratégia megvalósítása elengedhetetlen feladat mind az oktatási intézmények, mind a pedagógusok számára.

\section{Összegzés}

Kutatásunk célja többek között annak felmérése volt, hogy a pályaválasztás során mennyire befolyásolja a diákokat a digitális eszközök használata, azaz számít-e, hogy leendő munkájuk során alkalmazzák-e majd az IKT eszközöket és rendszereket, továbbá milyen tényezők befolyásolják legjobban a pályaválasztásban a diákokat. Milyen szintű digitális kompetenciával rendelkeznek? Van-e összefüggés az iskolai végzettség szintje és a digitalizációs pályaválasztás között? Az empirikus kutatásunk célcsoportját a Z-generációs nemzedék alkotta. A kutatás módszere a primer, kvantitatív alapú kutatások közül az online kérdőíves felmérés, amely közösségi hálózatok bevonásával került kiküldésre. Felméréseink alapján megállapítottuk, hogy a magasabb iskolai végzettség nincs hatással a pályaválasztással választott munkakör IKT igénye és szintje között. Másfelől arra is fény derült, hogy a magasabb iskolai végzettség között és a pályaválasztást befolyásoló okok között egyértelmű összefüggés van. A használt digitális eszközrendszereket tekintve nincs szignifikáns eltérés a fellehető primer kutatásokhoz képest.

További empirikus kutatásunk tárgyát képezi a jövőben tervezett felmérésünk keretében az itt bemutatott eredmények alapján a kérdéssor kiszélesítése, a következő kérdéskörök felvetésével: A diák az érdeklődési körének megfelelően választott pályára alkalmas-e, tisztában van-e saját képességeivel, ismeri-e erősségeit illetve fejlesztendő területeit? Tudják-e használni a megfelelő alkalmazásokat, a megkapott információval tudnak e mit kezdeni. 


\section{Irodalomjegyzék}

Balogh, Zoltán; Molnár, György; Nagy, Katalin ; Orosz, Beáta; Szúts, Zoltán (2020): A digitális kompetencia és a digitális kultúra társadalomra és oktatásra gyakorolt hatásai, jellemzői, kihívásai, CIVIL SZEMLE $17: 2$ pp. 69-88., 19 p. (2020)

Grail Research, 2011 és Segmentation by generation (marketingpower.com), Bardhi et al, 2010 alapján

György, Molnár; Zsolt, Námesztovszki; Dragana, Glušac; Dijana, Karuović; Lenke, Major (2020): Solutions, experiences in online education in Hungary and Serbia related to the situation caused by Covid-19, In: IEEE Proceedings of the 11th IEEE International Conference on Cognitive Infocommunications (CogInfoCom), New York (NY), Amerikai Egyesült Államok : IEEE (2020) pp. 603-607., 5 p.

https://doi.org/10.1109/CogInfoCom50765.2020.9237844

Howe, Neil - Strauss, William (2000): Millennials Rising: The Next Great Generation. Knopf Doubleday Publishing Group.

Microsoft News Center (2018): Van mit fejleszteni a Z-generáció digitális kompetenciáin, https://news.microsoft.com/hu-hu/2018/07/02/van-mit-fejleszteni-a-z-generacio-digitaliskompetenciain/, 2020.11.29.

Pál Eszter - Dr. Törőcsik Mária (2013) Irodalmi áttekintés a Z generációról, Pécsi Tudományegyetem Kiadó, 8. p.

Prensky, Marc (2001): Digital Natives, Digital Immigrants. On the Horizon 9/5: 1-6.

https://doi.org/10.1108/10748120110424816

R. Bögös Zsuzsanna, V. Dávid Mária (2003): Pályaválasztási feladatok az általános és középiskolában. In: V. Dávid, Mária (szerk): Pályaválasztási információk az iskolában. B.A.Z. Megyei Munkaügyi Központ, EKF, Eger. pp. 5-17.

Racsko Reka (2017). Digitális átállás az oktatásban. Bp., Gondolat Kiadó. Iskolakultúra. 52.

https://doi.org/10.17717/IQKONYV.Racsko.2017

Szakképzés 4.0 (2020). A Szakképzés és felnőttképzés megújításának középtávú szakmapolitikai stratégiája. A szakképzési rendszer válasza a negyedik ipari forradalom kihívásaira https://www.ikk.hu/files/Szakkepzes 4.0.pdf 64 o.

Szúts Zoltán (2018): Online: Az internetes kommunikáció és média története, elmélete és jelenségei, Budapest, Magyarország: Wolters Kluwer, ISBN: 9789632957784, pp 15-25. 